\title{
In-situ Formation of Mesoporous Silica Films Controlled by Ion Transfer Voltammetry at the Polarized Liquid-Liquid Interface
}

\author{
Lukasz Poltorak, Grégoire Herzog,* Alain Walcarius \\ LCPME, UMR 7564, CNRS - Université de Lorraine, 405 Rue de Vandœuvre, 54600 Villers-lès-Nancy, \\ France. \\ *email : gregoire.herzog@univ-lorraine.fr; T: +333836852 54;
}

This document is a postprint. Final version has been published in Electrochemistry Communications, 2013, 37, 76-79 (https://doi.org/10.1016/j.elecom.2013.10.018).

\begin{abstract}
Mesoporous silica films have been generated at the interface between two immiscible electrolyte solutions by ion transfer voltammetry of a surfactant template and self-assembly polycondensation of a hydrolysed silica precursor. A mesoporous silica film is formed at an oil-water interface, showing a 'wormlike' structure as confirmed by SAXS and TEM. The film structure was strongly influenced concentration of surfactant template (cetyltrimethylammonium tetrakis(4-chlorophenyl)borate). Free-standing mesoporous silica films can be also formed at micro-interface arrays and they remain permeable to the transfer of the model ion tetraethylammonium.
\end{abstract}

Keywords: Electrochemically assisted self-assembly, ITIES, surfactant template, free-standing silica film, micro-interface, tetraethylammonium. 


\section{Introduction}

Mesoporous thin films are attractive for a number of application fields such as energy, material science and analytical chemistry $[1,2]$. These films, which can be functionalized to induce specific properties, are usually formed by deposition onto a solid support by sol-gel chemistry. They can be obtained either by evaporation-induced self-assembly or by electrochemically assisted self-assembly, giving rise to well-ordered and even oriented structures [3]. A silica precursor is hydrolysed in the presence of a template agent (e.g. surfactants). The material is then formed upon self-assembly polycondensation of the silica precursor and the surfactant, giving to the film its structure and orientation, which depends from the experimental conditions (sol composition, aging, etc.) [4,5]. We report here the generation of a surfactant-templated mesoporous silica film, in-situ at the liquid-liquid interface, based on the combination of sol-gel chemistry and electrochemistry at the interface between two immiscible electrolyte solutions (ITIES). The generation of mesoporous structures at non-polarised liquid-liquid interfaces is not straightforward, although cooperative assembly of silica and surfactants at the oil-water and air-water interfaces was reported [6-8], but these were based on microemulsions (i.e. not as thin films) [7] or on synthetic methods difficult to control due to very long processing (i.e. days) [8]. Previous studies have reported the ITIES modification by adsorption of phospholipid monolayers, proteins, by electropolymerisation of terthiophene, by electrogeneration of silica films and by the support of zeolite, polymer, or silicon-fabricated membranes [9-12]. We investigated here the influence of experimental conditions ( $\mathrm{pH}$, precursor and surfactant concentrations) on the film formation and structure. The films were characterized by small-angle X-ray scattering (SAXS) and transmission electron microscopy (TEM) analysis. In a similar fashion, $\mu$ ITIES were modified to demonstrate the possibility of using these modified liquid-liquid micro-interfaces as sensors.

\section{Materials and Methods}

The silica precursor (tetraethoxysilane, TEOS) was dissolved in an aqueous solution of $5 \mathrm{mM} \mathrm{NaCl}, \mathrm{pH} 3$ and stirred for 1 hour at room temperature for hydrolysis. The $\mathrm{pH}$ was then adjusted to the desired value (with $\mathrm{HCl}$ and $\mathrm{NaOH}$ solutions). The organic phase was made of bis-(triphenylphosphoranylidene) ammonium tetrakis(4chlorophenyl)borate $\left(\mathrm{BTPPA}^{+} \mathrm{TPBCl}^{-}\right)$as the organic solution electrolyte and of cetyltrimethylammonium 
tetrakis(4-chlorophenyl)borate $\left(\mathrm{CTA}^{+} \mathrm{TPBCl}^{-}\right)$as the template molecule. Electrochemistry experiments were run in a custom-made borosilicate glass cell for the macro-ITIES experiments $\left(\mathrm{A}=2.83 \mathrm{~cm}^{2}\right)$ and at two sets of siliconfabricated array (30 pores of $10 \mu \mathrm{m}$ radius and 110 pores of $5 \mu \mathrm{m}$ radius) for the $\mu$ ITIES experiments [13]. The interface was polarised with a set of two reference $\mathrm{Ag} \mid \mathrm{AgCl}$ electrodes and two Pt mesh as counter electrodes. The electrochemical cell was $\mathrm{Ag}|\mathrm{AgCl}|$ Saturated $\mathrm{BTPPA}^{+} \mathrm{Cl}^{-}$in $10 \mathrm{mM} \mathrm{LiCl} \mid x \mathrm{mM} \mathrm{CTA}^{+} \mathrm{TPBCl}^{-}+10 \mathrm{mM}$ $\mathrm{BTPPA}^{+} \mathrm{TPBCl}^{-}$in 1,2-dichloroethane $\| y \mathrm{mM}$ TEOS $+5 \mathrm{mM} \mathrm{NaCl}$ in $\mathrm{H}_{2} \mathrm{O}|\mathrm{AgCl}| \mathrm{Ag}$. The pH of the aqueous phase was 9.5 unless stated otherwise; $1.5 \mathrm{mM}<x<14 \mathrm{mM} ; 50 \mathrm{mM}<y<300 \mathrm{mM}$. A potentiostat $302 \mathrm{~N}$ from Autolab (Metrohm, Switzerland) was used for cyclic voltammetry experiments. All films formed were cured at 130 ${ }^{\circ} \mathrm{C}$ for 16 hours to ensure cross-linking. The film formed at the macro-ITIES was carefully collected using a glass slide. Samples were placed between two sheets of Kapton ${ }^{\circledR}$ before exposition to X-Ray beam for about 5 min. Scattering of X-Ray beam was recorded according to the published procedure [18].

\section{Results and Discussion}

When the potential region is scanned from $+0.9 \mathrm{~V}$ down to $+0.05 \mathrm{~V}$, a negative peak is observed around $+0.1 \mathrm{~V}$ if both $\mathrm{CTA}^{+}$and TEOS are present in the electrochemical cell (Figure 1). The adsorption of $\mathrm{CTA}^{+}$ions at the interface might destabilise the interface and cause these spikes seen in Figure 1 (dotted curve) [15]. The peak at + $0.1 \mathrm{~V}$ is attributed to the transfer of $\mathrm{CTA}^{+}$from the organic to the aqueous phase. As it is only visible if both $\mathrm{CTA}^{+}$ and TEOS are present in the electrochemical cell, TEOS probably assists the transfer of $\mathrm{CTA}^{+}$to the aqueous phase. The presence of $\mathrm{CTA}^{+}$favours the polycondensation of TEOS around $\mathrm{CTA}^{+}$ensembles to form the silica film (Figure 1). In the reverse scan, a sharp peak at $+0.4 \mathrm{~V}$ is attributed to surfactant molecules transferring back to the organic phase. A similar behaviour was observed for the tetraoctadecyl ammonium transfer in the presence of liquid glass [16]. The charge under the reverse peak, showed maximum values for $\mathrm{pH}$ 9-10 before decreasing for $\mathrm{pH} 11$

(Figure 1B). $\mathrm{CTA}^{+}$transfer is the highest when polynuclear species $\left(\mathrm{Si}_{4} \mathrm{O}_{6}(\mathrm{OH})_{6}^{2-}\right.$ and $\left.\mathrm{Si}_{4} \mathrm{O}_{8}(\mathrm{OH})_{4}^{4-}\right)$ are predominant in the aqueous phase [17]. At $\mathrm{pH}$ lower than 9 and higher than 11, mononuclear species are dominant, which may not facilitate the transfer of $\mathrm{CTA}^{+}$to the aqueous phase. 

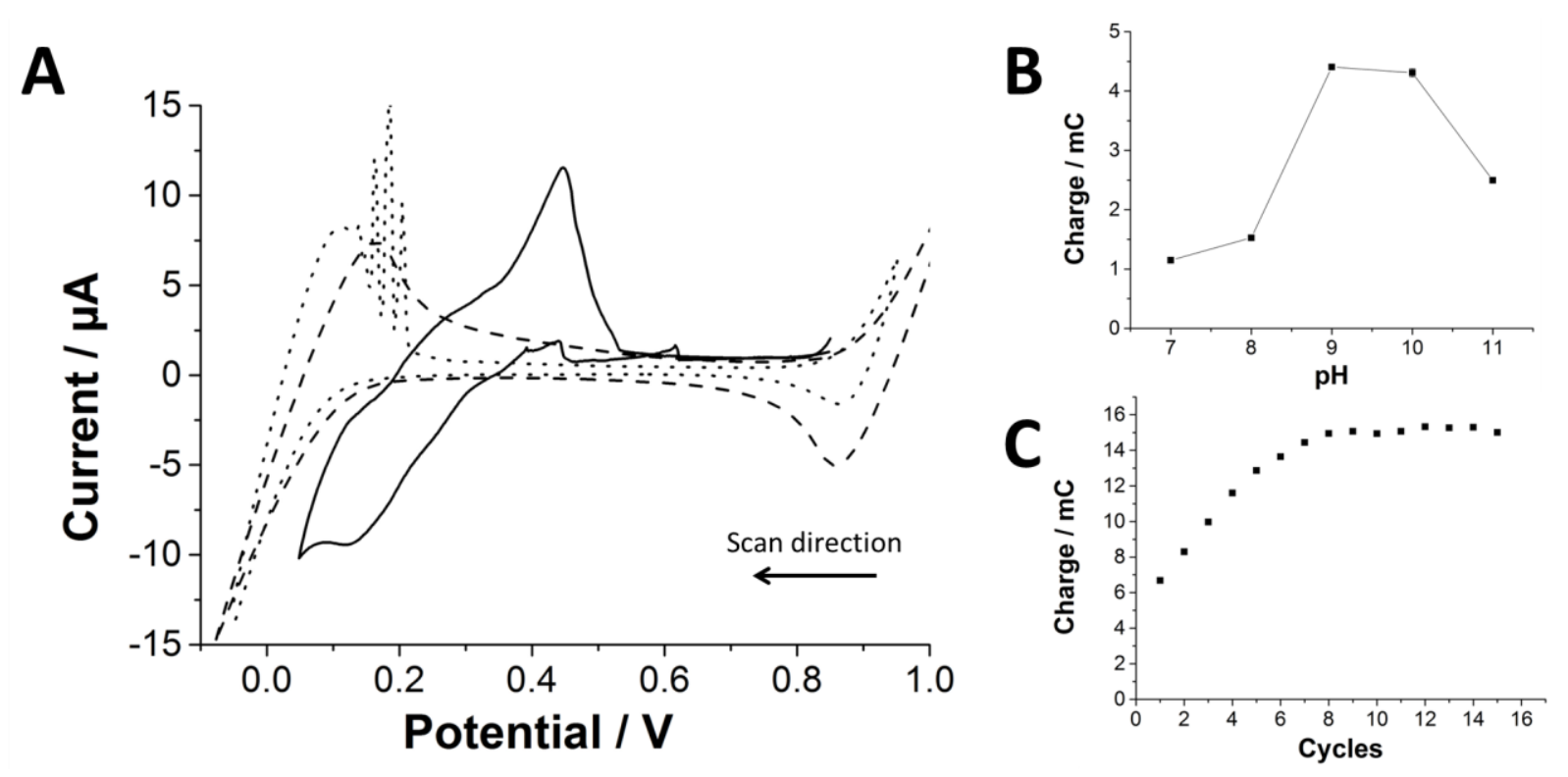

Figure 1. (A) Cyclic voltammograms (CV) in the presence of $50 \mathrm{mM}$ TEOS, and in the presence of $1.5 \mathrm{mM} \mathrm{CTA}^{+}$ (solid line); CVs in the absence of either $\mathrm{CTA}^{+}$(dashed line) or TEOS (dotted line) in the electrochemical cell; $v=$ $5 \mathrm{mV} \mathrm{s}^{-1}$. (B) Influence of $\mathrm{pH}$ on the reverse peak charge The charge is the average of the last five values of 15 consecutive CVs. $\left(\left[\mathrm{CTA}^{+}\right]_{\mathrm{org}}=3 \mathrm{mM}[\mathrm{TEOS}]_{\mathrm{aq} .}=300 \mathrm{mM}\right) .(\mathrm{C})$ Reverse peak charge as a function of the number of cycles $\left(\left[\mathrm{CTA}^{+}\right]_{\mathrm{org} .}=14 \mathrm{mM}\right.$ and $\left.\left.[\text { TEOS }]_{\mathrm{aq} .}=50 \mathrm{mM}\right) ; \mathrm{v}=5 \mathrm{mV} \mathrm{s}^{-1}\right)$.

The reverse peak charge increases upon repetitive cycling of the selected potential region until it reaches a plateau after 8 cycles approximately (Figure 1C), whereas the charge under the forward peak remains constant throughout the cycling. Silica is formed at the ITIES, induced by a voltammetrically controlled CTA ${ }^{+}$ion transfer. Indeed, no film formation was observed when an electrochemical cell was left for 16 hours at open-circuit potential at room temperature. These findings are consistent with previous observation of surfactant-templated silica films that were only obtained at the non-polarised oil-water interface after heating for $2-10$ hours at $150{ }^{\circ} \mathrm{C}$ [6]. The influence of $\mathrm{CTA}^{+}$and TEOS concentrations on the electrochemical process was investigated. The reverse peak charge, measured after 15 cycles, increased linearly with $\left[\mathrm{CTA}^{+}\right]_{\text {org. }}$ within the $1.5-14 \mathrm{mM}$ range (not shown), regardless of $[\text { TEOS }]_{\mathrm{aq} .}$. However, the reverse peak charge remained constant although $[\mathrm{TEOS}]_{\mathrm{aq}}$ increased (not shown). These results indicate that the film formation is really limited by the $\mathrm{CTA}^{+}$transfer. 
SAXS analysis of the films collected at the ITIES suggests the existence of a 'wormlike' structure as a broad signal was observed (especially visible on curves $b$ and $c$ in Figure 2). This level of order indicates that $\mathrm{CTA}^{+}$ions transferring to the aqueous phase are subject to cooperative self-assembly with TEOS molecules to form a surfactant-templated ordered film as shown by TEM analysis (Figure 2B\&C).

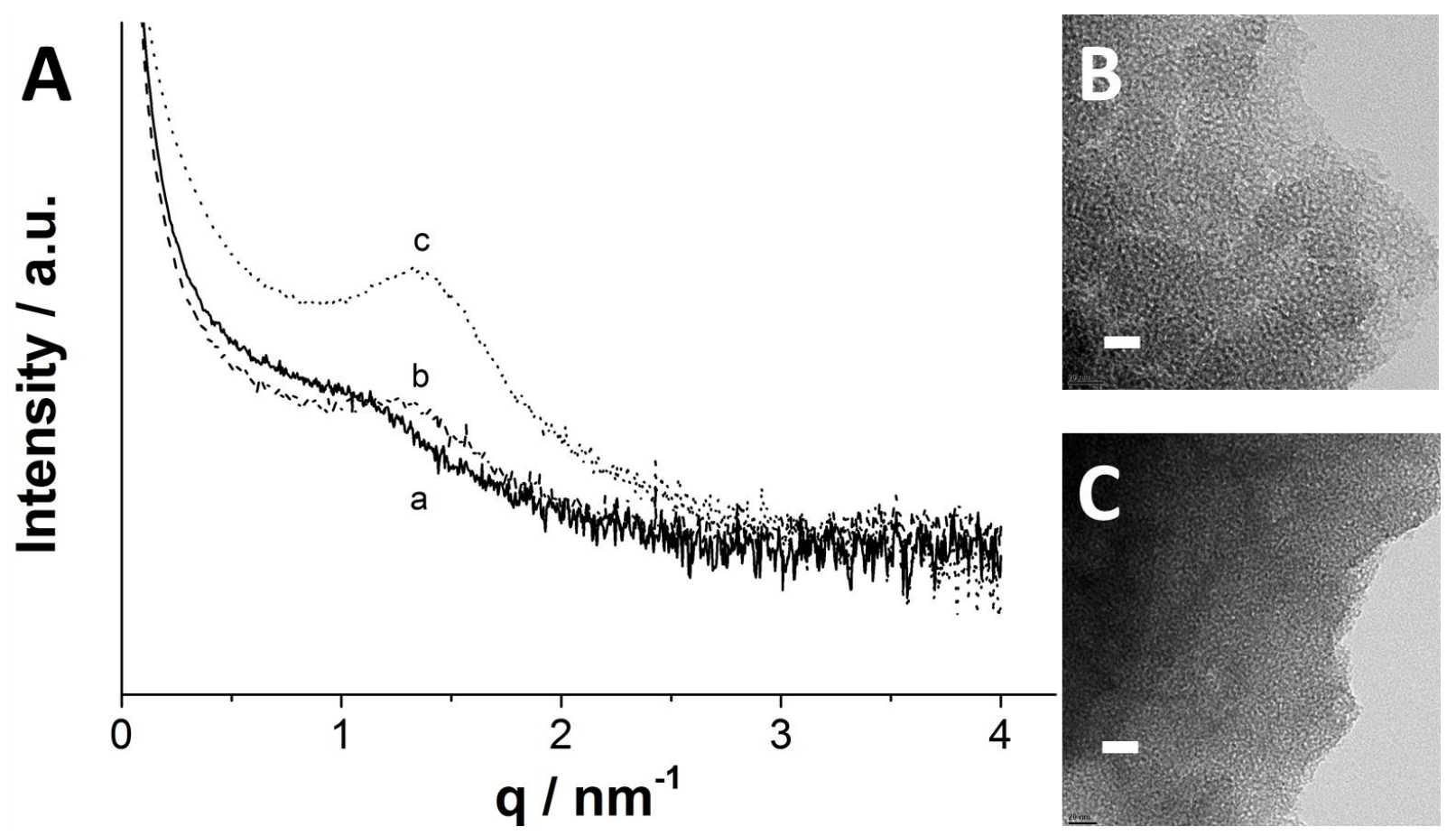

Figure 2. (A) Variation of SAXS pattern for different $\mathrm{CTA}^{+}$concentrations in the organic phase. The films were obtained by CV with $300 \mathrm{mM}$ TEOS in the aqueous phase and with (a) 5, (b) 10 and (c) $14 \mathrm{mM} \mathrm{CTA}^{+}$. TEM images of films prepared by cyclic voltammetry with $[\text { TEOS }]_{\text {aq. }}=300 \mathrm{mM}$ and $\left[\mathrm{CTA}^{+}\right]_{\text {org. }}=10 \mathrm{mM}(\mathrm{B})$ and $[\mathrm{TEOS}]_{\mathrm{aq} .}=300 \mathrm{mM}$ and $\left[\mathrm{CTA}^{+}\right]_{\mathrm{org} .}=14 \mathrm{mM}(\mathrm{C})$. Scale bars represent $20 \mathrm{~nm}$.

SAXS analysis was made for $3 \mathrm{CTA}^{+}$concentrations $(5,10$ and $14 \mathrm{mM})$ while $[$ TEOS] $=300 \mathrm{mM}$. The peak intensity increases with the concentration of $\mathrm{CTA}^{+}$in the organic phase and the pore center-to-center distance decreased from $5.7 \mathrm{~nm}\left(\left[\mathrm{CTA}^{+}\right]_{\text {org. }}=5 \mathrm{mM}\right)$ to $4.8 \mathrm{~nm}\left(\left[\mathrm{CTA}^{+}\right]_{\text {org. }}=10 \mathrm{mM}\right)$ and further down to $4.5 \mathrm{~nm}\left(\left[\mathrm{CTA}^{+}\right]_{\text {org. }}\right.$ $=14 \mathrm{mM})$. The impact of $\left[\mathrm{CTA}^{+}\right]_{\text {org. }}$ was expected as it influenced greatly the ion transfer charges measured during the cyclic voltammetry studies. The critical micelle concentration $(\mathrm{cmc})$ in water for $\mathrm{CTA}^{+} \mathrm{Cl}^{-}$is $1.4 \mathrm{mM}[18]$. As $\left[\mathrm{CTA}^{+}\right]_{\text {org. }}$ increases, the concentration of $\mathrm{CTA}^{+}$in aqueous diffusion layer is more likely to be above this cmc value 
leading to a structuration of the film formed. Note that decreasing the $[\text { TEOS }]_{\text {aq. }}$ has shown also an impact on the film structure, yet weaker than for $\left[\mathrm{CTA}^{+}\right]_{\text {org }}$, resulting in a small increase in the pore center-to-center distance $(e . g$. to $4.9 \mathrm{~nm}$ for $[\mathrm{TEOS}]_{\mathrm{aq} .}=50 \mathrm{mM}$ and $\left.\left[\mathrm{CTA}^{+}\right]_{\mathrm{org} .}=14 \mathrm{mM}\right)$.

Miniaturization of the ITIES leads to higher sensitivities, lower limits of detection and smaller $i R$ drop, analogously to phenomena observed for microelectrodes [11]. $\mu$ ITIES are generally obtained using a solid-state membrane pierced with holes of dimensions ranging from a few tens of nm up to a few tens of $\mu \mathrm{m}$, bringing mechanical stability to the system [11].
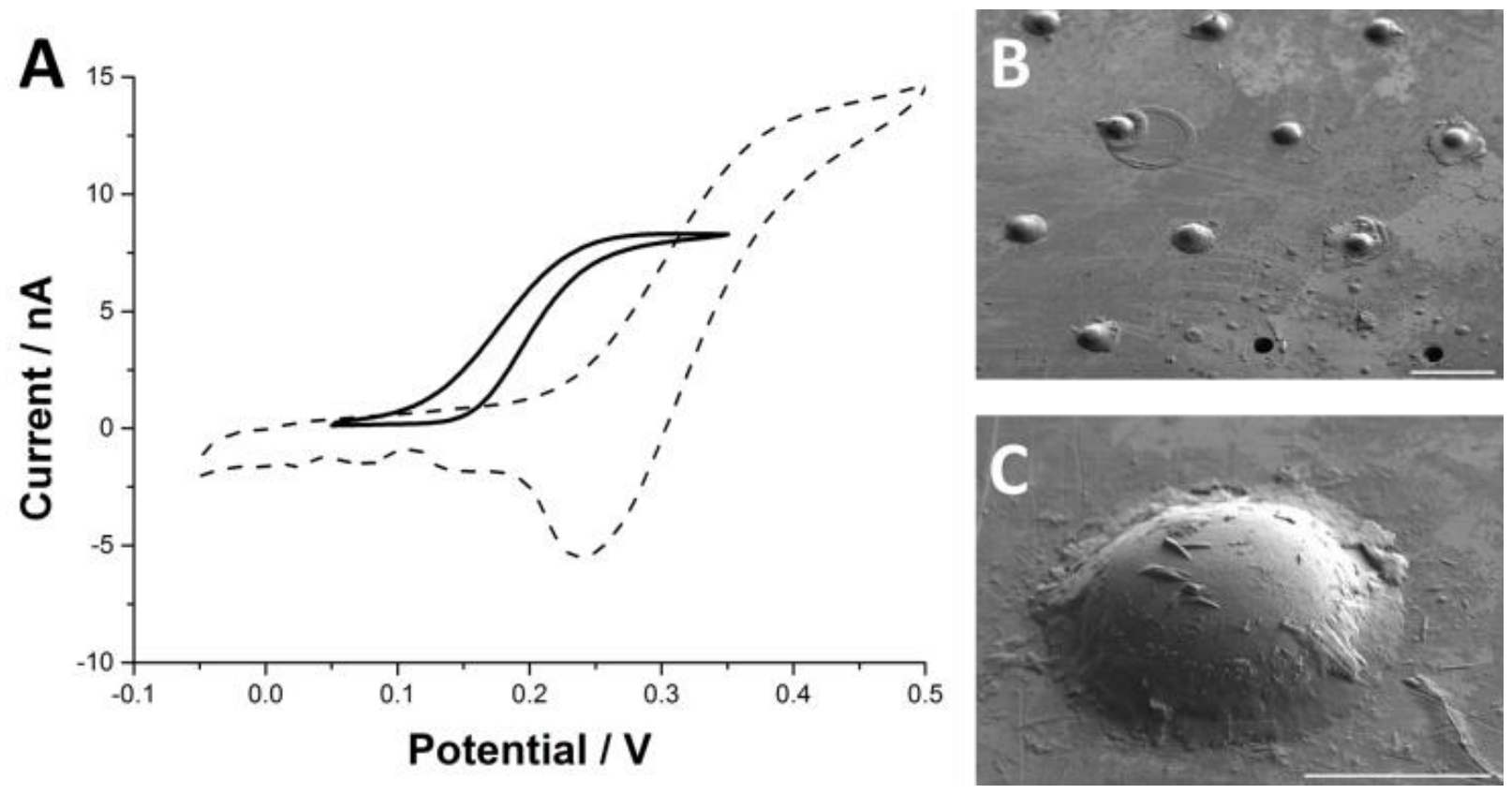

Figure 3. (A) CVs of $70 \mu \mathrm{M}$ of $\mathrm{TEA}^{+}$at a bare $\mu$ ITIES array (solid line), and at an array of $\mu$ ITIES modified with a mesoporous silica film generated by $\mathrm{CV}$ after $1 \mathrm{scan}$ (dotted line) $v=5 \mathrm{mV} \mathrm{s}^{-1}$. $[\mathrm{TEOS}]_{\mathrm{aq} .}=300 \mathrm{mM},\left[\mathrm{CTA}^{+}\right]_{\text {org. }}=$ $10 \mathrm{mM}(\mathrm{r}=10 \mu \mathrm{m}, \mathrm{N}=30)$. (B) SEM image of a modified $\mu$ ITIES array $(\mathrm{r}=5 \mu \mathrm{m}, \mathrm{N}=110$; scale bar represent 50 $\mu \mathrm{m})$. (C) SEM image of a single modified $\mu$ ITIES (scale bar represent $10 \mu \mathrm{m}$ ).

A microfabricated membrane ( $r=10 \mu \mathrm{m}, N=30$ pores) is modified by ion transfer voltammetry with 1 cycle using the same electrochemical cell as for the macroscopic cell. The permeability of these modified membranes was then analysed by cyclic voltammetry of $\mathrm{TEA}^{+}$(Figure 3 ). The presence of the silica film at the interface renders the $\mathrm{TEA}^{+}$transfer more difficult as it is shifted to more positive potentials. However, at the modified $\mu$ ITIES, a limiting 
current $i_{\text {lim }}=(13.3 \pm 0.03) \mathrm{nA}$ is obtained, which is higher than the current of $(7.8 \pm 0.02) \mathrm{nA}$ obtained at a bare $\mu$ ITIES. This experimental value is reasonably close to the theoretical value of $8.1 \mathrm{nA}$ obtained using the equation $i_{\text {lim }}=4 z F D C r N\left(z\right.$ is the charge transferred, $F$ is the Faraday constant, $D$ the TEA ${ }^{+}$diffusion coefficient, $C$ the TEA ${ }^{+}$ concentration, $r=10 \mu \mathrm{m}$ and $N=30$ pores in the array). The $i_{\text {lim }}$ increase is probably linked to an increase of the interface surface area due to the film formation outside the pores. SEM images of a modified $\mu$ ITIES array $(r=5$ $\mu \mathrm{m}, N=110$ pores) show hemispherical films towards the aqueous side of the interface. The $\mu$ ITIES are uniformly

covered by silica deposits, leaving the area between the $\mu$ ITIES unmodified (Figure 3B). This shape of films would correspond to the diffusion profile of the $\mathrm{CTA}^{+}$molecules when they transferred from the organic to the aqueous phase (Figure 3B\&C) before condensation of TEOS occurred. Indeed, the diameter of the film formed is $21.27 \pm$ $3.66 \mu \mathrm{m}$ (twice as large as the actual pore diameter $10.41 \pm 0.04 \mu \mathrm{m}[13])$. At the larger interfaces $(\mathrm{r}=10 \mu \mathrm{m})$, films protruding inside the aqueous phase were also formed, higher at the side of the interface and lower at the centre of interface (SEM image not shown). These observations suggest that diffusion of $\mathrm{CTA}^{+}$ions might be responsible for the shape of film rather than the interface. These experiments show that $\mu$ ITIES can be modified and allow ion transfer once modified. Investigations for a more thorough understanding of the film formation mechanism is still under-going.

\section{Conclusions}

Mesoporous silica films were prepared in-situ at both macro- and $\mu$ ITIES by transfer of $\mathrm{CTA}^{+}$ions, catalysing the polycondensation of hydrolysed silica precursors. The films remain permeable, suggesting that the control of the film chemistry by either co-condensation or post-synthesis functionalization would confer selectivity to $\mu$ ITIES modified with organic-inorganic hybrids, en route to a new class of electrochemical sensors. Selectivity of the sensors could be provided by the charge, the chemical function and the size of the target analyte and its possible interferents.

\section{Acknowledgments}


The project was partly supported by the Région Lorraine. The authors are grateful to J. Ghanbaja for the TEM imaging, to V. Jacque for preliminary studies, to A. Pasc, M.-J. Stébé and M. Emo for the SAXS measurements and to the Tyndall National Institute for provision of the microfabricated membranes.

[1] P. Innocenzi, L. Malfatti, Chem. Soc. Rev. 42 (2013) 4198-4216.

[2] A. Walcarius, Chem. Soc. Rev. 42 (2013) 4098-4140.

[3] M. Etienne, Y. Guillemin, D. Grosso, A. Walcarius, Anal. Bioanal. Chem. 405 (2013) 1497-1512.

[4] D. Grosso, F. Cagnol, G.J.A.A. Soler-Illia, E.L. Crepaldi, H. Amenitsch, A. Brunet-Bruneau, A. Bourgeois, C. Sanchez, Adv. Funct. Mater. 14 (2004) 309-322.

[5] A. Walcarius, E. Sibottier, M. Etienne, J. Ghanbaja, Nature Mater. 6 (2007) 602-608.

[6] L. Faget, A. Berman, O. Regev, Thin Solid Films 386 (2001) 6-13.

[7] S. Schacht, Q. Huo, I.G. Voigt-Martin, G.D. Stucky, F. Schüth, Science 273 (1996) 768-771.

[8] K.J. Edler, B. Yang, Chem. Soc. Rev. 42 (2013) 3765-3776.

[9] R.A.W. Dryfe, Phys. Chem. Chem. Phys. 8 (2006) 1869-1883.

[10] H.H. Girault, in:, A.J. Bard, C.G. Zoski (Eds.), Electroanalytical Chemistry, Vol. 23, CRC Press, Boca Raton, 2010, pp. 1-104.

[11] D.W.M. Arrigan, G. Herzog, M.D. Scanlon, J. Strutwolf, in:, A.J. Bard, C.G. Zoski (Eds.), Electroanalytical Chemistry, Vol. 25, CRC Press, Boca Raton, 2013, pp. 105-178.

[12] J. Niedziolka, M. Opallo, Electrochem. Commun. 10 (2008) 1445-1447.

[13] J. Strutwolf, M.D. Scanlon, D.W.M. Arrigan, Analyst 134 (2009) 148-158.

[14] J. Jacoby, A. Pasc, C. Carteret, F. Dupire, M.J. Stébé, V. Coupard, J.L. Blin, Process Biochem. 48 (2013) 831-837.

[15] T. Kakiuchi, J. Electroanal. Chem. 536 (2002) 63-69.

[16] V. Mareček, H. Jänchenová, J. Electroanal. Chem. 558 (2003) 119-123.

[17] C.F. Baes Jr, R.E. Mesmer, Hydrolysis of Cations, John Wiley and Sons, New York, 1976.

[18] L. Sepulveda, J. Cortes, J. Phys. Chem. 89 (1985) 5322-5324. 